"Please do not cite without permission."

\title{
Lead Independent Director: Impact on Firm Performance and Financial Misstatements
}

\section{INTRODUCTION}

A key controversial issue over the board leadership structure in corporate governance is whether a company’s CEO should also serve as the Chairman of its Board of Directors (known as CEO-Chair duality). Shareholder activists have lobbied for separating the roles of Chairman of the Board from that of the Chief Executive Officer (CEO), arguing that the CEO-Chair duality leads to lack of independent monitoring of corporate managements. ${ }^{1}$ A representative of Calpers, for instance, argued at the Exxon Mobil annual shareholders' meeting that combining the CEO-Chair roles is like "grading your own exam papers.”

However, there is little research support for separating the CEO-Chair roles. As Finkelstein, Hambrick, and Cannella (2009) note, CEO-Chair duality can benefit from the stronger stewardship role that the duality status will enable. The Consumer Protection Act (2010) addresses the corporate governance implications of CEO-Chair duality. Under Item 407(h) the SEC requires disclosure of a company's board leadership structure, including whether and why the company has chosen to combine or to separate the chief executive officer and board chairman positions. A company is also required to state why the company believed that its leadership structure is the "most appropriate structure for it at the time of filing." If the same

\footnotetext{
${ }^{1}$ For example, in a high-profile case in 2013, Jamie Dimon of J.P.Morgan had to fend off a strong challenge of his dual CEO-Board Chair role from public employee unions and the New York City Comptroller.
} 
person serves as both board chairman and CEO, the company must disclose whether the board has a lead independent director and that director's role.

The above SEC's rule implies that a lead independent director (LID) might be a good alternative to separating the positions of $\mathrm{CEO}$ and board chair by reducing the negative corporate governance implications of CEO-Chair duality. The LID could provide a counterbalance to the Chair, especially in instances of CEO-Chair duality, serve a conduit of information between the board members, the board chair and its stakeholders and provide a check on the Chair's powers to ensure that the Chair is acting with objectivity and independence. The LID could help resolve disputes relating to the CEO/Chair by serving as an independent arbiter. The LID can also ensure an independent performance evaluation of the Chair by engaging non-executive directors effectively in the process. In spite of the perceived benefits of a LID, as we discuss below, there is a dearth of empirical evidence in the literature regarding the corporate governance implication of a lead independent director.

In our study, we examine the corporate governance impact of a LID. Specifically, we investigate whether the existence of a lead independent director is associated with firm performance and/or financial misstatements. We consider this issue in the light of the CEOChair duality status of corporate boards - in other words, is there an incremental corporate governance benefit to having a LID in companies with CEO-Chair duality, as opposed to companies in which the CEO and Chair are two different individuals?

Using a sample of Fortune 1000 companies in year 2013, we find that the effect of lead independent director on firm performance hinges on CEO -Chair duality. That is, for companies with CEO-Chair duality, the existence of a lead independent director is positively associated with improved firm performance as measured by Tobin's Q. In contrast, we do not find a similar 
association for companies separating the positions of CEO and board chair. In addition, we do not find an association between the existence of a lead independent director and the likelihood of misstatements. These results suggest that the existence of a lead independent director is helpful in alleviating at least some of the negative corporate governance aspects of CEO-Chair duality.

Our study makes a number of contributions to the literature. First, we examine a dimension (lead independent director) of board structure that complements aspect like CEOChair duality that has been considered in prior research. Second, our study adds to the research on the interplay between the LID and CEO-Chair duality. Finally, our study provides empirical evidence to support SEC’s rule regarding the disclosures of corporate board structures that derives from the Consumer Protection Act of 2010.

The remainder of this paper is organized as follows. The next section discusses the theoretical foundations and relevant literature on CEO-Chair duality and lead independent directors and derives our hypotheses. Subsequent sections present the methodology employed to investigate relationships and empirical results. The final section concludes with a discussion of our findings and contributions.

\section{LITERATURE REVIEW AND HYPOTHESIS DEVELOPMENT}

As Finkelstein, Hambrick, and Cannella (2009) note, CEO-Chair duality is a contentious issue in public discussions of corporate governance. Concerned shareholders frequently argue that having the same person serve as both CEO and chair diminishes the independence of the board and leads to a lack of oversight of corporate management. This argument is based on agency theory, according to which separating the CEO and Chair roles increases the board's independence from management, leading to better monitoring of management. As the board is 
directly responsible for the hiring and firing of the CEO, and is charged with general oversight of the corporation's affairs and its management on behalf of the shareholders, installing the CEO as Chairman could indicate a conflict of interest. An outside, non-executive chairman, they argue, helps to enhance the independent oversight of management and more closely aligns the work of the board with the interests of shareholders. Proponents of splitting the CEO-chair roles also contend that an independent chairman is able to ensure that the board is fully and objectively engaged with strategy and can evaluate how well it is being implemented. The SECs additional disclosure requirement on board structure has increased shareholders’ attention to this issue. Recent cases in which the SEC required the CEOs of companies such as Tesla and Renault to relinquish their Board Chair positions on allegations of financial misstatements have fueled the trend towards separating the two roles (Sun, 2019).

On the other hand, stewardship theory would suggest that the benefits of separating the CEO and chair roles are not so clearly evident. This is based on the argument that the dual role provides a unity of command resulting in a strong, central leadership and clear authority that is essential for effective management. This is the main reason that executives, boards and regulators have not been quick to embrace the board structure proposed by shareholder activists. The CEO has superior knowledge of the operations of the business and when that role is unified with his role as Chairman of the Board, it potentially enhances his or her ability to lead the corporation and to identify any problems that may arise. A CEO-Chair can also provide superior knowledge to the board and increase the information available to it, leading to an efficient board structure. The other board members can have confidence that their Chairman/CEO is fully aware of the corporation's strengths and weaknesses, along with what issues need to be addressed 
moving forward. Corporate executives also indicate that there is little evidence that having a separate chairman improves shareholder returns.

A case in point is the heavy machinery company, Caterpillar. While the company had split its CEO and Chair roles due to shareholder pressure, the company decided to re-combine the two positions in 2019, when the company's CEO, Jim Umpleby, was named chairman nearly two years into his tenure. The board felt it was in the best interest of the company to combine the roles, Caterpillar spokeswoman Corrie Scott said in an emailed statement. "Under Jim’s leadership, Caterpillar introduced a new strategy and has already made great progress on implementing priorities to profitably grow the company," she said. "He also led the company to deliver solid financial performance, including record quarterly profit per share in each quarter of 2018 reported to date.” (Sun, 2019

Because of the inherent trade-off between the centralization of command associated with duality and the independent oversight associated with a separate board chair, CEO-Chair duality is referred as a "double-edged sword". Empirical evidence on the effect of CEO-Chair duality is mixed. For example, while Rechner and Dalton (1991) and Pi and Timme (1993) find that companies have combined position of CEO-Chair underperform those with a separate board chair, Brickley et al. (1997) find the opposite results.

Given the trade-off inherent in CEO-Chair duality and the mixed empirical evidence, academic researchers (e.g., Lipton and Lorsch, 1992; Lorsch and Lipton 1993), regulators and corporate governance advocates consider that appointment of a lead independent director $\mathrm{n}$ the case of CEO-Chair duality might be a practical way to overcome the agency problems associated with the CEO-Chair role and to mitigate the potentially negative effects of the duality. Krause et 
al (2017) argue that the power balance between the CEO and the board determines the appointment of a LID and the managerial implication is that this structure allows the CEO to remain as Chair while maintaining effective corporate governance. In this spirit, the U.S. Securities Exchange Commission (SEC) has mandated increased disclosures relating to corporate board structures following the Consumer Protection Act of 2010 (effective March 2010). The new Item 407(h) requires disclosure of a company’s board leadership structure, including whether and why the company has chosen to combine or to separate the chief executive officer and board chairman positions. A company is also required to state why it believed that its leadership structure is the "most appropriate structure for it at the time of filing." If the same person serves as both board chairman and CEO, the company must disclose whether the board has a lead independent director and that director's role.

RiskMetrics Group, a prominent corporate governance advocate, developed a proxy voting policy with respect to independent chair shareholder proposals:

“Under its voting policies, proxy advisor RiskMetrics generally recommends a vote for shareholder proposals requiring that the chairman's position be filled by an independent director, unless the company maintains all the elements of the following counterbalancing governance structure: Designated lead director, elected by and from the independent board members with clearly delineated and comprehensive duties. (The role may alternatively reside with a presiding director, vice chairman, or rotating lead director; however, the director must serve a minimum of one year in order to qualify as a lead director.)”

As an illustration of the responsibilities of a lead independent director, see the following from Google’s 2014 proxy statement. 
"In addition, in April 2007, our board of directors appointed John L. Hennessy as our Lead Independent Director. As Lead Independent Director, John's responsibilities include:

- Coordinating and moderating executive sessions of the board of directors' independent directors.

- Advising the executive chairman of the board of directors as to the quality, quantity, and timeliness of the flow of information from management that is necessary for the independent directors to perform their duties effectively and responsibly.

- Confirming the agenda with the Chief Executive Officer for meetings of the board of directors.

- Holding regular update sessions with the executive chairman of the board of directors.

- Acting as the principal liaison between the independent directors and the executive chairman of the board of directors on sensitive issues.

- Performing such other duties as the board of directors may from time to time delegate to the Lead Independent Director to assist the board of directors in the fulfillment of its responsibilities.”

Based on the above responsibilities, the role of a lead independent director is intended to complement the functions of the Executive Chairman and Chief Executive Officer, resulting in enhancing board effectiveness. The existence of the lead independent director is also expected to alleviate the agency problem associated with the CEO-Chair duality.

. As such, we propose our first two hypotheses as follows:

\section{H1: There is a positive association between the existence of a lead independent director and firm performance.}




\section{H2: The positive association between lead independent director and firm performance will be stronger for the companies with CEO-Chair duality.}

Board structure also affects management behavior when the firm performance has been subpar. Weisbach (1988) finds that "there is a stronger association between prior performance and the probability of a resignation for companies with outsider-dominated boards than for companies with insider-dominated boards”, which indicates that CEO has stronger career concerns following bad performance in a company with better corporate governance. As such, if the existence of a lead independent director leads to better corporate governance, CEO and CFO from a company with a lead independent director might have more incentive to misstate the financial statements. For example, they might underestimate bad debt expense and overstate the expected future benefits of certain assets.

On the other hand, the presence of a lead independent director can potentially serve as a mechanism to monitor management. This is because the lead director provides an avenue of independent communication between shareholders and the board and between the board/Audit Committee and external auditors. For example, Microsoft 2014 proxy statement states: “ ........ The Board believes its programs for overseeing risk, as described in this Part 2 under "Risk oversight," would be effective under a variety of leadership frameworks and therefore do not materially affect its choice of structure. See "Shareholder communication with directors" in this

Part 2 for information about how to communicate with the lead independent director....." Thus, the presence of a lead independent director potentially mitigate the likelihood of financial misstatements.

Based on the above discussion, we specify our third hypothesis (non-directional) as follows:

H3: There is an association between the existence of a lead independent director and 


\section{the likelihood of financial misstatements.}

\section{DATA AND ANALYSIS METHODS}

\subsection{Data and Sample}

Our sample consists of Fortune 1000 companies for year 2013. We obtained data on lead independent directors from S\&P Capital IQ. Financial data (firm size, sales, leverage, etc.) and stock ownership data (CEO ownership, institutional ownership etc.) are from S\&P Capital IQ and Calcbench. Daily stock returns and data on firm age are from CRSP. The restatement data are from Audit Analytics. After accounting for missing data, our final sample consists of 777 firms for the analysis of firm performance and 711 firms for the analysis of financial misstatements.

3.2 Lead Independent Directors and Firm Performance: Test of H1 and H2

For the $\mathrm{H} 1$ and H2, the main dependent variable is Tobin’s Q, which is a commonly used market-based measure of firm performance (e.g., Lang et al.,1989; Chung and Pruitt, 1994).

To examine our first hypothesis, we estimate the following regression model:

$$
\begin{aligned}
& \text { Tobin's } \mathrm{Q}=\beta_{0}+\beta_{1} \text { Lead }+\beta_{2} \text { Size }+\beta_{3} \text { Leverage }+\beta_{4} \text { ROA }+\beta_{5} \text { CEO-Hold }+ \\
& \beta_{6} \text { Institutional_Hold }+\beta_{7} \text { Firmage }+\sum \beta_{j} \text { INDUSTRY } \_ \text {DUMMY }{ }_{j}+\varepsilon \text {. }
\end{aligned}
$$

This model contains the main variable of interest: Lead, which is coded as one if a company has a lead independent director, and zero otherwise. We also include additional variables to control for firm size (Size), leverage (Leverage), profitability (ROA), firm age (Firmage) and stock ownership (CEO_Hold and Institutional_Hold). In addition, industry dummy variables are included into the model to control the industry fix effects.

Based on $\mathrm{H} 1$, we expect that $\beta_{1}>0$.

To examine our second hypothesis, we estimate the following regression model: 
Tobin's $\mathrm{Q}=\beta_{0}+\beta_{1}$ Lead $+\beta_{2}$ Lead $*$ CEO_Duality $+\beta_{3}$ CEO_Duality $+\beta_{4}$ Size + $\beta_{5}$ Leverage $+\beta_{6} \mathrm{ROA}+\beta_{7} \mathrm{CEO}$-Hold $+\beta_{8}$ Institutional_Hold $+\beta_{9}$ Firmage $+\sum \beta_{j} I N D U S T R Y{ }_{-} D U M M Y_{j}+\varepsilon$.

This model includes the addition of two new variables to the previous specification. First, CEO_Duality is a dummy variable, which indicates whether a company separates the role of board chair from CEO. In addition, Lead*CEO-Duality captures the impact of CEO-Chair duality on the association between lead independent director and firm performance.

Based on Hypothesis two, we expect that $\beta_{2}>0$.

3.3 Lead Independent Directors and Financial Misstatements: Test of H3

To examine our third hypothesis(H3), we estimate the following logistic regression model:

$$
\begin{aligned}
& \text { Restate }=\beta_{0}+\beta_{1} \text { Lead }+\beta_{2} \text { Size }+\beta_{3} \text { SalesVolatility }+\beta_{4} \text { CashFlowVolatility } \\
& +\beta_{5} \text { Loss } \%+\beta_{6} \text { Return }+\beta_{7} \text { SalesGrowth }+\beta_{8} \text { CEO_Hold }+\beta_{9} \text { Analysts }+\beta_{10} \text { Institutional- } \\
& \text { Hold }+\beta_{11} \text { Insider_Hold }+\quad \beta_{12} \text { Activist_Hold } \quad+\beta_{13} \text { Firmage }+ \\
& \sum \beta_{j} \text { INDUSTRY_DUMMY } Y_{j}+\varepsilon .
\end{aligned}
$$

We develop the above logistic regression model based on Demerjian et. al. (2013) and Khan (2019). We include most of financial control variables identified by these two papers, such as firm size, sales volatility, cash flow volatility, and percentage of losses. In addition, we add a set of corporate governance related control variables, such as CEO ownership and Institutional shareholder ownership etc.

\section{EMPIRICAL RESULTS}

Descriptive statistics for our sample are presented in Table 1. Panel A and Panel B show the descriptive statistics for the firm performance analysis sample and financial misstatements analysis sample respectively. The descriptive statistics present a number of interesting 
observations about the lead independent director. On average, approximately 79\% companies have a lead independent director. Panel A shows that roughly 53\% companies have CEODuality. These two numbers suggest that many companies separating CEO and Board Chair also have a lead independent director ${ }^{2}$. In addition, our descriptive statistics indicate that on average approximately $1 \%$ of a company's stock are owned by CEO and the average firm age is around 32 years. Panel B shows that approximate 15.5\% companies restated financial statements in year 2013.

\section{$<$ Insert Table 1>}

Table 2 presents the results of our OLS model with Tobin's Q as the dependent variable, and the lead independent director (Lead) as the independent variable of interest. The adjusted-R squares of 0.58 indicates that the explanatory power of this model is relatively high. Consistent with our prediction, the coefficient of Lead is positive. However, the p-value (0.315) indicates that the effect of Lead on Tobin's Q is not significant. Thus, our first hypothesis is not supported. $<$ Insert Table 2>

Table 3 presents the results of testing H2, with Tobin's Q as the dependent variable and the interaction term (Lead*CEO-Duality) as the independent variable of interest. Consistent with the results in Table 2, there is no significant association between Lead and Tobin’s Q. However, consistent with our prediction in $\mathrm{H} 2$, the coefficient of Lead*CEO-Duality is positive and significant, which suggests that the effect of Lead on firm performance as measured by Tobin's Q is stronger for the companies with CEO-Duality. Therefore, our second hypothesis is

\footnotetext{
${ }^{2}$ For example, both Google and Microsoft have a lead independent director even though they have separate CEOs and Board Chairs. By examining their latest proxy statements, we find that both companies do not consider their board chair an independent director.
} 
supported. Furthermore, the p-value of the joint test (Lead+Lead*Duality=0) is 0.067 , indicating that the existence of a lead independent director is positively associated with improved firm performance for the companies with CEO-Duality. Interestingly, companies separating the positions of CEO and board chair do not have a significant association between lead independent director and firm performance, because the main effect of Lead on Tobin's Q is insignificant (pvalue $=0.231$ ).

\section{$<$ Insert Table 3>}

Table 4 presents the results of testing H3, with Restate as the dependent variable and the lead independent director (Lead) as the independent variable of interest. The coefficient of Lead is positive (0.193) but not significant ( $p$-value $=0.494$ ), suggesting that the two opposite effects of the existence of a lead independent director on the financial misstatements might offset each other.

$$
<\text { Insert Table 4> }
$$

\section{SUMMARY AND CONCLUSIONS}

While a significant number of firms have welcomed the idea of "CEO-Chair duality + lead independent director” by appointing a lead independent director, there has been little empirical evidence about the impact of lead independent director on board monitoring effectiveness. This study presents empirical evidence regarding the effect of lead independent director on corporate governance.

We find that the effect of lead independent director on firm performance hinges on CEO -Chair duality. That is, for companies with CEO-Chair duality, the existence of a lead independent director is positively associated with improved firm performance as measured by 
Tobin's Q. In contrast, we do not find a similar association for companies separating the positions of CEO and board chair. In addition, we do not find an association between the existence of a lead independent director and the likelihood of misstatements. These results suggest that the existence of a lead independent director is helpful in improving board monitoring effectiveness.

To our knowledge, our study is among the first to examine the effect of lead independent director on board monitoring effectiveness. In addition, our study provides empirical evidence to support SEC’s new rule regarding the disclosures of corporate board structures.

Future research regarding the effect of lead independent director could examine other positive governance outcomes like CEO turnover following poor performance, minimizing accounting and management scandals, and preventing excessive CEO compensation. In addition, future research could examine key characteristics of the lead independent director and determine whether specific characteristics increase their ability to be more effective in performing their monitoring functions. 


\section{References}

Brickley, J. A., J. L. Coles, and G. Jarrell, 1997. Leadership structure: Separating the CEO and chairman of the board. Journal of Corporate Finance 3:189-220.

Chung, K.H., and Pruitt, S.W. 1994. A simple approximation of Tobin's q. Financial Management 23(3): 70-74.

Demerjian, P., B. Lev, M. Lewis, and S. McVay. 2013. Managerial ability and earnings quality. The Accounting Review 88 (2): 463-498.

Finkelstein, S., Hambrick, D. C., \& Cannella, A. A., Jr. 2009. Strategic Leadership: Theory and Research on Executives, Top Management Teams, and Boards. New York, NY: Oxford University Press.

Khan,S. 2019. CFO Outside Directorship and Financial Misstatements. Accounting Horizons 33 (4): 59-75.

Krause, R., Withers, M.C., Semadeni, M. 2017. Compromise on the Board: Investigating the Antecedents and Consequences of Lead Independent Director Appointment. Academy of Management Journal. Vol. 60, Issue 6, p. 2239-2265

Lang, L. H., Stulz, R., and Walkling, R. A. 1989. Managerial performance, Tobin's Q and the gains from successful tender offers. Journal of financial Economics 24(1):137-154.

Lipton, M., and J. W. Lorsch, 1992. “A modest proposal for improved corporate governance”, Business Lawyer 48: 59-77.

Lorsch, J. W. and M. Lipton, 1993. "On the Leading Edge: The Lead Director," Harvard Business Review 71-1, 79-80.

Pi, L. and S. G. Timme, 1993. Corporate control and bank efficiency. Journal of Banking \& Finance 17: 515-530.

Rechner, P. L. and D. R. Dalton, 1991. CEO duality and organizational performance: A longitudinal analysis. Strategic Management Journal 12:155-160.

Sun, M. 2019. More U.S. Companies Separating Chief Executive and Chairman Roles. The Wall Street Journal, January 23, 2019.

The U.S. Securities and Exchange Commission (SEC). Item 407(h) of Regulation S-K [17 CFR 229.407(h)].

Weisbach, M. S. 1988. Outside directors and CEO turnover. Journal of financial Economics 20: 431-460. 
Table 1: Descriptive Statistics

Panel A: Sample for the analysis of firm performance ( $\mathrm{N}=777)$

\begin{tabular}{lrrrrr}
\hline Variable & Mean & $\begin{array}{r}\text { Lower } \\
\text { Quartile }\end{array}$ & Median & $\begin{array}{r}\text { Upper } \\
\text { Quartile }\end{array}$ & Std Dev \\
\hline Tobin's Q & 1.735 & 0.937 & 1.380 & 2.114 & 1.431 \\
Lead & 0.788 & 1.000 & 1.000 & 1.000 & 0.409 \\
CEO-Duality & 0.533 & 0.000 & 1.000 & 1.000 & 0.499 \\
Size (millions) & 38511.520 & 4025.500 & 8833.500 & 23038.300 & 159638.939 \\
Leverage & 0.253 & 0.113 & 0.237 & 0.366 & 0.174 \\
ROA(\%) & 6.577 & 3.370 & 5.660 & 8.580 & 4.719 \\
CEO_Hold(\%) & 1.180 & 0.063 & 0.166 & 0.418 & 4.777 \\
Institutional_Hold(\%) & 82.818 & 74.000 & 85.930 & 94.080 & 16.773 \\
Firmage & 31.411 & 15.000 & 25.000 & 42.000 & 22.465
\end{tabular}

Panel B: Sample for the analysis of financial misstatement $(\mathrm{N}=711)$

\begin{tabular}{lrrrrrr}
\hline \multicolumn{1}{c}{ Variable } & Mean & $\begin{array}{r}\text { Lower } \\
\text { Quartile }\end{array}$ & Median & $\begin{array}{c}\text { Upper } \\
\text { Quartile }\end{array}$ & Std Dev \\
\hline Restate & 0.155 & 0.000 & 0.000 & 0.000 & 0.362 \\
Lead & 0.799 & 1.000 & 1.000 & 1.000 & 0.401 \\
Size(millions) & 40439.920 & 3979.300 & 8844.800 & 23186.100 & 166498.009 \\
SalesVolatility & 0.075 & 0.019 & 0.047 & 0.093 & 0.094 \\
CashFlowVolatility & 0.025 & 0.010 & 0.019 & 0.032 & 0.023 \\
loss\% & 0.080 & 0.000 & 0.000 & 0.143 & 0.146 \\
Return & 0.330 & 0.084 & 0.270 & 0.462 & 1.087 \\
SalesGrowth & 0.073 & 0.005 & 0.050 & 0.112 & 0.166 \\
CEO_Hold(\%) & 1.197 & 0.063 & 0.169 & 0.416 & 4.913 \\
Analysts & 23.515 & 16.000 & 22.000 & 29.000 & 10.935 \\
Institutional_Hold(\%) & 82.914 & 74.030 & 85.840 & 94.080 & 16.477 \\
Insider_Hold(\%) & 3.556 & 0.399 & 0.934 & 2.670 & 7.620 \\
Activist_Hold(\%) & 1.872 & 0.233 & 0.655 & 1.830 & 3.310 \\
Firmage & 32.291 & 16.000 & 27.000 & 43.000 & 22.279 \\
\hline
\end{tabular}




\section{Variable Definitions:}

Tobin's $Q$ is ratio of (market value of equity + book value of debt) to book value of assets.

Restate is a dummy variable which is coded as one if a company restated financial statements in year 2013, and zero otherwise.

Lead is a dummy variable which is coded as one if a company has a lead independent director, and zero otherwise.

CEO_Duality is a dummy variable which is coded as one if a company's CEO also serves as board chairman, and zero otherwise.

Size is the log of a company's total assets.

Leverage is the total debt over total assets.

ROA is the net income over total assets.

SalesVolatility is the stand deviation of [sales/average total assets] in last five years.

CashFlowVolatility is the stand deviation of [operating cash flow/average total assets] in last five years.

Loss\% is the percentage of years having negative net income in last five years.

Return is the one year buy and hold stock return.

SalesGrowth is current year's sales growth.

CEO_Hold is ratio of outstanding stocks held by CEO.

Institutional_Hold is ratio of outstanding stocks held by institutional investors.

Insider_Hold is ratio of outstanding stocks held by insiders.

Activist_Hold is ratio of outstanding stocks held by activist investors.

Firmage is the log of the number of years since the firm went public.

Note: Size and Firmage are in their raw format in Table 1, but we use their log transformations for the rest of Tables given the skewness of these two variables. 
Table 2: The association between lead independent director and firm performance (Test of Hypothesis One)

Dependent Variable $=$ Tobin's $Q$

\begin{tabular}{lccc}
\hline VARIABLES & $\begin{array}{c}\text { PRED. } \\
\text { SIGNS }\end{array}$ & $\begin{array}{c}\text { ESTIMATED } \\
\text { COEFFICIENTS }\end{array}$ & P-VALUE \\
\hline Intercept & & 3.573 & $<.0001^{* * *}$ \\
Lead & + & 0.040 & 0.315 \\
Size & $?$ & -0.217 & $<.0001^{* * *}$ \\
Leverage & - & -0.082 & 0.344 \\
ROA & + & 0.181 & $<.0001^{* * *}$ \\
CEO_Hold & $?$ & 0.024 & $0.001^{* * *}$ \\
Institutional_Hold & + & -0.011 & $<.0001^{* * *}$ \\
Firmage & $?$ & -0.130 & $0.002^{* * *}$ \\
Industry Fixed Effect & Controlled & & \\
Adj $\mathbf{R}^{2}$ & & 0.582 & \\
$\mathbf{N}$ & & 777 & \\
\hline
\end{tabular}

All variables are defined in Table 1. P-values are based on one tailed (two tailed) tests for variables whose relation to the dependent variables is (is not) predicted. $(*),\left({ }^{* *}\right),\left({ }^{* * *}\right)$ indicates significance at the $0.10,0.05$, and 0.01 levels, respectively. 
Table 3: The impact of CEO_Duality on the association between lead independent director and firm performance (Test of Hypothesis Two)

Dependent Variable $=$ Tobin's $Q$

\begin{tabular}{|c|c|c|c|}
\hline VARIABLES & $\begin{array}{l}\text { PRED. } \\
\text { SIGNS }\end{array}$ & $\begin{array}{c}\text { ESTIMATED } \\
\text { COEFFICIENTS }\end{array}$ & P-VALUE \\
\hline Intercept & & 3.652 & $<.0001 * * *$ \\
\hline Lead & + & -0.076 & 0.231 \\
\hline Lead*CEO_Duality & + & 0.334 & $0.047 * *$ \\
\hline CEO_Duality & $?$ & -0.212 & 0.253 \\
\hline Size & $?$ & -0.221 & $<.0001 * * *$ \\
\hline Leverage & - & -0.070 & 0.366 \\
\hline ROA & + & 0.182 & $<.0001 * * *$ \\
\hline CEO_Hold & $?$ & 0.024 & $0.002^{* * *}$ \\
\hline Institutional_Hold & + & -0.011 & $<.0001^{* * *}$ \\
\hline Firmage & $?$ & -0.131 & $0.001 * * *$ \\
\hline Industry Fixed Effect & Controlled & & \\
\hline Joint test: Lead+Lead*Duality=0 & + & 0.259 & $0.067^{*}$ \\
\hline Adj R ${ }^{2}$ & & 0.583 & \\
\hline $\mathbf{N}$ & & 777 & . \\
\hline
\end{tabular}

All variables are defined in Table 1. P-values are based on one tailed (two tailed) tests for variables whose relation to the dependent variables is (is not) predicted. $(*),(* *),\left({ }^{* * *}\right)$ indicates significance at the $0.10,0.05$, and 0.01 levels, respectively. 
Table 4: The association between lead independent director and the likelihood of financial misstatements (Test of Hypothesis Three)

Dependent Variable $=$ Restate

\begin{tabular}{lccc}
\hline VARIABLES & $\begin{array}{c}\text { PRED. } \\
\text { SIGNS }\end{array}$ & $\begin{array}{c}\text { ESTIMATED } \\
\text { COEFFICIENTS }\end{array}$ & P-VALUE \\
\hline Lead & $?$ & 0.193 & 0.494 \\
Size & + & 0.338 & $0.009^{* * *}$ \\
SalesVolatility & + & -0.460 & 0.705 \\
CashFlowVolatility & + & 5.409 & 0.304 \\
Loss\% & + & -0.480 & 0.547 \\
Return & $?$ & -0.035 & 0.777 \\
SalesGrowth & $?$ & 1.155 & $0.073^{*}$ \\
CEO_Hold & $?$ & 0.011 & 0.725 \\
Analysts & $?$ & -0.078 & $<.0001^{* * *}$ \\
Institutional_Hold & Controlled & & 0.127 \\
Insider_Hold & & 0.013 & 0.830 \\
Activist_Hold & $?$ & 0.005 & $0.001^{* * *}$ \\
Firmage & $?$ & 0.099 & \\
Industry Fixed Effect & & & 0.048 \\
Pseudo R & & & \\
N & $?$ & & \\
\hline
\end{tabular}

All variables are defined in Table $1 .\left({ }^{*}\right),\left({ }^{* *}\right),\left({ }^{* *}\right)$ indicates significance at the $0.10,0.05$, and 0.01 levels, respectively. 